\title{
Cognitive Enhancement and Network Effects: how Individual Prosperity Depends on Group Traits
}

\section{Jonathan Anomaly ${ }^{1}$ (D) $\cdot$ Garett Jones ${ }^{2}$}

Received: 21 November 2019 / Accepted: 4 February 2020 /

Published online: 22 February 2020

(C) The Author(s) 2020

\begin{abstract}
A central debate in bioethics is whether parents should try to influence the genetic basis of their children's traits. We argue that the case for using mate selection, embryo selection, and other interventions to enhance heritable traits like intelligence is strengthened by the fact that they seem to have positive network effects. These network effects include increased cooperation in collective action problems, which contributes to social trust and prosperity. We begin with an overview of evidence for these claims, and then argue that if individual welfare is largely a function of group traits, parents should try to preserve or enhance cognitive traits that have positive network effects.
\end{abstract}

Keywords Intelligence $\cdot$ Patience $\cdot$ Cognitive enhancement $\cdot$ Moral enhancement $\cdot$ Network effects

\section{Introduction}

Many traits that we value are the product of evolution by natural and sexual selection. Evolution is a blind process that causes heritable traits that increase fitness to proliferate. It does not necessarily favor traits - or levels of a trait — that are optimal from the perspective of our well-being or the long-term survival of our species (Powell and Buchanan, 2011).

We are lucky. We have the power to understand the process that produced us, reflect on the traits that make our lives go better, and try to steer evolution in a direction that we choose. At least some of the traits that nature has bequeathed us can increase our

Jonathan Anomaly

anomaly@upenn.edu

Garett Jones

gjonesb@gmu.edu

1 Philosophy, Politics, and Economics Program, University of Pennsylvania, Philadelphia, PA 19104, USA

2 Economics Program, George Mason University, Fairfax, VA 22030, USA 
well-being independent of their effects on our ability to survive and reproduce. Heritable traits like intelligence, empathy, and creativity can lead us to produce lasting achievements that we value, ranging from great works of art and scientific discovery to meaningful relationships.

Some of these traits also predict cooperation at a group level. We review evidence indicating that when average intelligence is raised in a population, perhaps up to some threshold, each member of the group is likely to lead a better life than if intelligence were relatively low. We then argue that standard considerations in favor of genetic enhancement are strengthened by these network effects. ${ }^{1}$ Finally, we argue that since we cannot count on either uncoordinated individual choice or centralized state power to produce patterns in which average abilities are raised, we should explore the conditions under which norms are likely to emerge that direct us to make socially beneficial reproductive choices.

\subsection{How Group Traits Affect Individual Welfare}

Sometimes the whole is more than the sum of its parts. In this section, we review the evidence for a connection between the average traits of a group and the success of the individuals who comprise it. While we focus on general intelligence, in part because it is so widely studied, scientists are beginning to uncover the genetic roots of other psychological traits that have similar properties (Plomin, 2018). Examples include individualism, and the tendency to defer to impersonal rules rather than kinship loyalties, which some argue were inadvertently selected for via marriage patterns and social norms imposed by the Catholic Church in Western Europe (Schulz et al., 2019).

As usual, Charles Darwin anticipated the broad claim we're making: "It is most difficult to say why one civilised nation rises, becomes more powerful, and spreads more widely, than another; or why the same nation progresses more at one time than at another. We can only say that it depends on an increase in the actual number of the population, on the number of men endowed with high intellectual and moral faculties, as well as on their standard of excellence" (1871, p. 140). The welfare of groups depends on both the heritable traits of those who comprise them, and on the moral norms and political institutions that create social order.

Humans are the only animal species whose members routinely and peacefully cooperate with other unrelated members of the same species (Seabright, 2004). Adam Smith pointed out a version of this claim when he said that humans have a propensity to "truck, barter, and exchange" (1776, Book 1, Chapter 2). While anthropologists have debated just how universal that propensity is, it's entirely accurate to say that exchange is vastly more common among humans than among other animal species.

Economic exchange is only the most elementary form of cooperation. Working on team projects and sharing the benefits, helping a neighbor plow the snow in her

\footnotetext{
${ }^{1}$ Network effects occur when adding another user of a good or another person with a trait to a population tends to make others within that population better off. For example, as more people adopted personal computers, the value of owning one increased, and so did the power of computers to help us accomplish our goals. In other words, network effects are positive externalities that increase as the number of users of a good or people with a trait increase in a population. Throughout the paper we will use "network effect" to mean positive network effects, even though this term is occasionally applied to traits or technologies that have increasingly negative effects as they are adopted.
} 
driveway after a storm, giving up a little in this month's political battle because that's better than raising the probability of a low-grade civil war: all are examples of cooperation based on long-run reciprocity, which helps make the group better off even if the individual has to pay a short-run cost.

The canonical metaphor for such behavior - for trusting one's partner today in the hope of building a lasting, productive relationship — is the repeated prisoner's dilemma. If people enter a prisoner's dilemma thinking they're just playing a one-time game, then a rational person who has no fellow-feeling for his opponent has only one reasonable option: defect - in other words, don't be taken for a sucker. But if the same game is repeated for a long time - either endlessly or with a modest chance of ending each round - then a new, pro-social outcome becomes possible, and a strategy of conditional cooperation becomes rational even in the absence of altruistic motivation.

If we know we'll be meeting the same partner each day for a long time, and we each need to decide whether to trust or distrust each other that day, this one-time game is converted into an entirely new game, a repeated prisoner's dilemma, even if the benefits and costs of one-time trust and distrust remain unchanged. In this repeated game, if we both start off playing nice the first day, and then after that first success each player decides to do whatever the other player did the day before, then we've entered the world of Tit-for-Tat, a strategy first formalized by the psychologist Anatol Rapaport, but anticipated by the biologist Robert Trivers and game theorist John von Neumann.

If both players follow a Tit-for-Tat rule, we'll see harmonious cooperation, with each player encouraging the other to cooperate through the threat of retaliation. The magic of a credible threat of retaliation is that it doesn't have to be implemented to work. Tit-forTat is a successful strategy when each party values the future benefits of harmony more than the present joys of cheating; a faithful marriage might be a useful analogy. There are real benefits to forming a lasting union with a partner even if there are immediate advantages to cheating.

Social emotions like love, shame, and guilt evolved in part to impose additional psychological costs on cheaters (Darwin 1872, Frank 1988). Rational people with prosocial emotions can become trustworthy traders because they see the advantages of Titfor-Tat, but also because they are known to exhibit 'strong' reciprocity that includes a sense of pride in following mutually beneficial strategies, and shame in being the first to break from such a strategy (Frank 2001, Bowles and Gintis 2011, Anomaly 2017). ${ }^{2}$ Patience is another important cognitive trait that fosters our ability to follow a strategy of long-run reciprocity: the threat of punishment looms larger in the minds of people who are more patient.

As Jones (2016, Ch. 4) discusses, there is a vast empirical literature spanning psychology and economics showing that intelligence scores are a useful predictor of patience, of foresighted behavior. Whether it's people in a lab experiment being asked hypothetical questions about whether they'd rather have $\$ 50$ today or $\$ 75$ in a year, or

\footnotetext{
${ }^{2}$ Sam Bowles and Herb Gintis distinguish a 'weak' disposition to play Tit-for-Tat with 'strong' reciprocity, which includes moral emotions associated with justice: "In experiments we commonly observe that people sacrifice their own payoffs in order to cooperate with others, to reward the cooperation of others, and to punish free-riding even when they cannot expect to gain from acting this way. We call the preferences motivating this behavior strong reciprocity, the term "strong" intended to distinguish this set of preferences from entirely amoral and self-regarding reciprocation that would not be undertaken in the absence of some payback" (2011, p. 20).
} 
enlisted members of the U.S. military deciding whether to take a (genuine) $\$ 10,000$ lump-sum payment now rather than a thousand dollars a year for twenty years, people who get higher scores on IQ tests tend to place more weight on the future.

And this willingness to focus on the future shows up in cooperation games as well. Of the four reported experiments where investigators checked to see if the average IQ of a pair of players predicted average rates of cooperation in a repeated prisoner's dilemma, the correlation was positive in all four, and statistically significant in three of the four. The most recent study (Proto et al., 2019) conforms quite closely to the scenario described above: students took an IQ test as part of an experiment, and then were brought in on a later day to play a repeated prisoner's dilemma that had (in some cases) a $25 \%$ probability of ending each round. Unbeknownst to the students, on that second day, students were paired by IQ score: students with above above-average scores were paired with each other, and likewise with the below-average scoring students. And the pairs of players with above-average scores were exceptionally likely to reach $100 \%$ rates of cooperation, while those with below-average scores cooperated much less often.

Note the relevant finding here: it's not that higher-IQ individuals are more cooperative, other things equal. It's that higher-IQ pairs are more cooperative. Smarter people aren't nicer as a rule - although they do appear in experiments to have some tendency to start off nicer in a game, perhaps in an attempt to get cooperation off the ground. The apparent kindness of the intelligent in the early rounds of these games is consistent with enlightened self-interest, of making a risky investment now that might pay off by creating a bigger pie down the road. Jones (2016) refers to this kind of shrewd, piegrowing, intelligence as "Coasian Intelligence," after economic Nobelist Ronald Coase. The Coase Theorem showed that if people are good at bargaining, and if bargaining costs are low, people can always find a bargain that maximizes social welfare even if their society has started off with bad, inefficient rules. Wise people can bargain around bad rules. Coasian Intelligence is a step beyond Machiavellian intelligence - the more cynical view that human intelligence is an evolved tool that helps us exploit other people. Coasian Intelligence reminds us that often the best way to exploit another person is to make that person better off-and it appears that higher-IQ groups of players can do that in the lab.

But do these lab lessons extend to the real world? Is it likely that by raising the average measured intelligence of a group we will increase conventionally measured levels of social capital, trust and trustworthiness, and other indicators of social wellbeing? Or are these experiments just reporting that smarter people are better at playing mentally demanding games?

One way of responding to these questions is that life is itself a mentally demanding game. A well-cited paper in psychology is entitled "Everyday Life as an Intelligence Test" (Gordon, 1997). Equally, one could entitle a paper "Everyday Life as a Repeated Prisoner's Dilemma." Our lives are social, success relies on repeated interactions with those around us, and many of us behave differently when the time horizon appears short - so the analogy from the lab to the real-world isn't much of a stretch. At the same time, other evidence can be brought to bear on the question of whether high group intelligence is likely to create higher, more effective levels of social intelligence. One form of evidence is that people with higher IQs tend to do noticeably better on tests of emotional intelligence. The most famous, most academically robust measure of 
emotional intelligence, the MSCEIT, has a moderate correlation with IQ, around 0.2 (Jones, 2016). Smarter individuals are more likely to be able to read the emotions of others and better able to create plausible solutions to emotionally difficult situations. And when IQ tests and the MSCEIT are run in a horse race to see which better predicts work performance, the IQ test wins easily.

The only important empirical question is whether the MSCEIT helps a little in predicting work performance when used along with an IQ test or whether it's just acting as a low-quality IQ test. If we value living around people who are emotionally intelligent and reasonably pro-social, then raising the average IQ of groups appears to be a useful path to that goal.

Another key channel through which the cognitive skills of our neighbors is likely to matter is through voting. Whether voters are well-informed or poorly-informed can have a large effect on policy outcomes, and those with higher IQs are more likely to have accurate information about government just as they're more likely to have accurate information about everything else - indeed, a wide-ranging trivia test is part of any typical long-form IQ test. And Caplan and Miller (2010) show that at least within the U.S., those with higher IQs are more likely to support market-oriented policies, a relationship that survives a number of statistical controls including income and education. Nations with more residents who can see Adam Smith's invisible hand are more likely to support market-oriented policies, and politicians who worry about the unintended consequences of intuitively-appealing government interventions. Voting is a world of side effects, where the political attitudes of my neighbors shape the policies that I'll be living under. So genetic and environmental interventions that raise the mental skills of the average citizen in my country will tend to improve the political system I live under, and thereby tend to improve my life.

Taken together, these relationships between group IQ and Coasian cooperation, and between group IQ and informed voting mean that we should expect to see less corrupt, more market-oriented policies in countries with higher test scores. A variety of papers have found this to be the case, even after controlling for other confounding factors. Potrafke (2012), Jones and Potrafke (2014), and Kanyama (2014) have all reported robust relationships between national average IQ and a variety of measures of national quality of economic institutions. The first two of these papers also showed that the result holds for another measure of national test scores as well, one derived from the PISA, TIMSS, and PIRLS international schooling assessments. The lab and survey evidence appear consistent with the cross-country data: Our neighbors shape our government, so it's reasonable to believe that cognitive enhancements that improve our neighbors intelligence will tend to improve our governments.

In addition to these political channels of cognitive enhancement, the well-established finding that the intelligent tend to be more frugal and farsighted means that they're likely to have higher rates of savings, a predicted correlation that holds across countries (Jones, 2016, ch. 4). And since a surprisingly high fraction of a nation's savings appears to be "locked" inside one's own country - a finding known as the Feldstein-Horioka savings puzzle - then if a sizable number of people in our nation become more frugal, our entire nation tends to benefit, because a sizable portion of those additional investment funds tend to stay in our nation. This helps even those citizens who aren't so frugal: if your bank has a lot of funds to loan out because your neighbors are frugal, that helps you when you apply for a loan, even if you're not particularly frugal yourself. 
Those funds, once lent out, can build the local stock of physical capital and thereby boost local productivity. Frugal neighbors help all of us, even the not so frugal.

Those with higher IQ scores also tend to differ from others when it comes to taking risks. They're more willing to take the kinds of risks involved when one invests in stocks - in particular, they tend to have a lower degree of risk aversion (Dohmen et al., 2010). Likewise, a recent review article coauthored by Nobel laureate James Heckman reports that risk-tolerance was greater both for those with higher scores on a verbal IQ test as well as on a visual pattern-finding IQ test (Almlund et al., 2011). Similar results were reported in a study of Chilean high school students: "We find that higher cognitive ability-especially mathematical ability-is predictive of much lower levels of smallstakes risk aversion." (Benjamin et al., 2013).

But do these experimental results linking test scores and risk tolerance show up in the real world? Or is this just a lab result? The answer matters for asset allocation and very likely for long-run economic performance, since young firms and innovative firms tend to be high-risk ventures that often fail or underperform, but which can hand out handsome rewards to those willing to bear the risk, and which on average are highreturn investments. If IQ-type mental abilities influence risk-taking, this would shape the entire economy. Drawing on an astonishingly wide collection of Finnish datasetsand drawing in part on IQ tests given to Finnish citizens entering mandatory military service - Grinblatt et al. (2011) report that IQ appears to have a bigger effect than income on stock market participation. The overall pattern of results has been replicated for a broad European sample. According to Christelis et al, "the propensity to invest in stocks is strongly associated with cognitive abilities, for both direct stock market participation and indirect participation through mutual funds and retirement accounts" (2010, p. 18).

Less intelligent people know they are more likely to be ripped off in the stock market, and this is likely a reason they shun it - a wise choice for them as individuals. But it means fewer risky gambles for the nation as a whole-gambles that, in the aggregate, tend to generate innovation and higher productivity. The intelligent are also more likely to steer their funds prudently, taking risks while simultaneously managing those risks. Having a larger group of citizens who are informed enough, patient enough, and risk-tolerant enough to fund promising risky ventures is a path to national prosperity.

In the richest countries, the most economically crucial sectors tend to be exceptionally complex, with differing elements that require coordinating across thousands of workers. Auto manufacturing, telecommunications equipment, pharmaceuticals, and blockbuster moviemaking are just a few examples. If a weak movie score reduces a blockbuster movie's sales by just $1 \%$, that mistake could cost the production company ten million dollars. Economist Michael Kremer (1993) showed that in such an economy - an O-ring economy, as he called it, since a single mistake could be as disastrous as the explosion of the space shuttle Challenger, caused by a single faulty $\mathrm{O}$ ring - it's exceptionally important to pair the best workers with each other.

The skills of our neighbors influence the tasks our economy can take on: this finding is backed up by recent studies showing that countries with higher average IQs have higher levels of economic complexity as proxied by Ricardo Hausmann's new Economic Complexity Index (Azam, 2017). Unsurprisingly, this correlation survives a variety of controls for possible confounds. The mental abilities associated with a high 
IQ include the ability to keep lots of facts in mind at once- a form of mental multitasking. And once we recall the higher average emotional intelligence of the conventionally intelligent, it's little surprise that nations with higher standardized test scores tend to take on the most economically complex tasks.

Since our neighbors shape the economic options available to us - they shape the economic rules we live by, the amount of money available at our banks, the types of business plans that are funded, and the level of complexity of our most important businesses - policies that improve our neighbors' cognitive skills will very likely tend to increase our individual prosperity. The best studied of these cognitive skills is human intelligence, proxied by IQ scores. Other traits that could have large spillover effects should also be explored. Conscientiousness is a leading candidate, as is patience, which some economists are exploring as an independent factor in shaping the wealth of nations (Dohmen et al., 2010). Economies are social processes, and social processes are made up of interactions between individuals. This is one reason it is important to understand which traits have strong network effects and which do not.

\subsection{Moral Reasons for Cognitive Enhancement}

A number of influential moral philosophers have defended the view that we should use biomedical technology to enhance cognition and moral character. A common argument for enhancing cognition is that since general intelligence predicts well-being on a wide variety of measures, ranging from physical health and financial success to mental health and relationship stability (Plomin and Deary, 2015), prospective parents should think about the cognitive characteristics of their kids (Bostrom and Sandberg, 2009). An argument for enhancing empathy (or other traits that underlie pro-social behavior) is that people with higher levels of affective empathy are more likely to contribute to public goods or cooperate in collective action problems (Persson and Savulescu, 2017). ${ }^{3}$ In short, a number of arguments have been given in favor of cognitive enhancement, and moral enhancement. But if the evidence above is right, cognitive enhancement can also be thought of as a form of moral enhancement.

This is true in at least two ways. First, if cognitive enhancement produces better outcomes, including greater material wealth, this is good from a moral point of view to the extent that human welfare matters. Second, wealthier societies with high levels of trust make it less risky for people to behave generously. Even people with benevolent motives are less likely to behave generously when they think others are a threat (Powell and Buchanan, 2016). To some extent, then, cognitive enhancement can be seen as a form of moral enhancement. More to the point, there are moral reasons to cognitively enhance people, provided it is safe to do so, if smarter people tend to create the conditions for more productive social interactions. As Allen Buchanan argues, "any enhancement that increases human productivity will tend to have network effects, because if more people are individually more productive, they will be able to work together more productively" (2011, p. 118).

\footnotetext{
${ }^{3}$ Though, importantly, the most obvious way of doing this involves manipulating oxytocin - a drug which increases parochial altruism, and ethnocentrism, not unconditional or universal altruism (De Dreu et al., 2010). It is unclear whether it's possible, or even desirable, to simply increase general empathy toward all people.
} 
Philosophers can learn a lot from the sciences. In particular, evolutionary biologists can give us a sense of the psychological mechanisms that helped our ancestors cooperate in collective action problems. Economists have a different but complementary toolkit that highlights how incentives work in groups of different sizes, how transaction costs and information asymmetries affect collective action, and how institutions can shape our preferences in ways that are conducive to cooperation and prosperity. Although scientists can show us some of the conditions under which cooperation is more likely to materialize, they cannot tell us how we ought to organize societies, all things considered.

One of the goals political institutions should try to achieve is to create conditions in which people tend to make socially beneficial reproductive choices - that is, choices that are likely to benefit their own children (Savulescu and Kahane, 2009), and other people with whom their children will interact (Douglas and Devolder, 2013). As John Rawls argued in A Theory of Justice, people concerned with intergenerational justice should be motivated to create institutions that "insure for their descendants the best genetic endowment (assuming their own to be fixed). The pursuit of reasonable policies in this regard is something that earlier generations owe to later ones" (1971, p. 107). Generally, this will involve leaving parents free to influence the traits of their children through mate selection, embryo selection, and gene editing. ${ }^{4}$ But individual choices always occur against the backdrop of social norms, which are shaped by legal institutions. So it's worth thinking about which kinds of political institutions are likely to create the conditions for socially beneficial reproductive norms to emerge (Gyngell and Douglas 2015, Anomaly 2020). ${ }^{5}$

According to legal scholar Richard McAdams, norms are "informal social regularities that individuals feel obligated to follow because of an internalized sense of duty, because of a fear of external non-legal sanctions, or both" (1997, p. 340). When they work well, norms help us economize on information, and make choices that benefit large groups of people in ways that members of the group don't fully understand (Hayek, 1960). Simple examples of social norms are rules that indicate how we should greet one another, which forms of dress are appropriate at a wedding or a funeral, and what counts as a fair way to allocate scarce resources in a group. While social norms differ between societies in ways that reflect local conditions, they help coordinate people's choices without any one person needing to think much about the origin or content of the norms they follow.

Norms are often more desirable than government mandates as ways of coordinating our actions. This is especially true of reproductive choices. Even if future people will be better off if current people make responsible choices, politicians typically lack the incentives and information to appropriately manage our choice to have kids. Moreover, laws can be more expensive to enforce than norms since they require an army of paid police officers, a costly system of courts, and sometimes objectionable incursions on

\footnotetext{
${ }^{4}$ We think that in the near future embryo selection using gametes derived from induced pluripotent stem cells is the most likely technology to significantly raise the cognitive capacities of future people. The process might be sped up dramatically by using iterated embryo selection (Sparrow, 2014, Shulman and Bostrom, 2014), but for now iterated embryo selection remains in the realm of science fiction.

${ }^{5}$ While there are reasons to cede reproductive choice to individuals, it is plausible to think that group selection has been a powerful source of traits that enable human cooperation (Wilson and Wilson, 2007), so the formal institutions and informal norms that shape our reproductive choices are likely to remain important.
} 
the liberty of citizens. Norms can be cheaper to enforce than laws because they are usually backed by moral emotions like guilt and shame, and by psychological incentives like our desire for the esteem we get from other people when we follow social norms.

The biggest problem with relying solely on norms to shape choices in a way that's likely to boost socially beneficial traits is that most of us now live in large cities within even larger nations. These are not the conditions in which norms tend to be most effective at coordinating human actions to produce net gains (Ostrom, 2000).

In fact, the reproductive patterns that have emerged in large liberal societies are neither adaptive nor desirable from the standpoint of human flourishing across generations. Richerson and Boyd emphasize that in virtually all developed market societies, maladaptive reproductive norms have taken hold (2005, chapter 5). The core idea is that although smaller families enable individuals to secure more resources, wealthy people who enjoy high levels of freedom seem to take less of an interest in using their resources to produce children. The demographic pattern Richerson and Boyd identify is partly explained by the cost of raising children in developed countries, including the opportunities one has to forgo in societies where wealth and leisure time allow us to pursue intellectually stimulating activities. Moreover, when people we admire have very few children, the rest of us tend to copy them. Most of us are inclined to follow the lead of successful and high-status individuals (Henrich, 2015).

Maladaptive reproductive norms in the developed world have led to subreplacement fertility - with especially low fertility rates among those with more education, more income, and a higher IQ. ${ }^{6}$ This pattern isn't inevitable, though it seems to be spreading across the world as educational opportunities for women increase, along with economic growth and secularization.

\subsection{Enhancing Cognition by Altering Institutions}

We now explore some ideas for how specific laws and general political institutions might facilitate the emergence of norms that raise average intelligence.

\subsubsection{Family Policy}

Nordic countries like Sweden, Norway, and Finland have among the most generous family leave policies in the world - with options for either parent to be compensated for staying home with children for an extended period after a child is born. Most family leave policies also contain provisions preventing employers from discriminating against pregnant women or firing them for taking leave after they have a child. Reducing the risk that potential parents will experience serious setbacks to their career, in addition to compensating parents while they care for newborns, could spur a change in social norms so that it is considered normal, even praiseworthy, for professionals to build a family.

\footnotetext{
${ }^{6}$ Satoshi Kanazawa (2014) reviews the data and argues that education and IQ do not have an independent negative correlation with fertility, contrary to what others have found. We do not take a position on this issue.
} 
Family leave policies may be a good idea simply from the standpoint of justice, since women's labor during and after pregnancy generally goes uncompensated, and the social benefits of smart people having children are widely dispersed. But family leave laws seem to have only a modest effect on fertility. At first, evidence indicated that generous family leave policies in Nordic countries were successful at nudging birthrates up toward replacement levels, in particular by targeting professionals who otherwise find it difficult to leave a career and take care of children. But since 2009, fertility rates among native Nordics have declined (even though overall fertility has stabilized because of higher fertility rates among immigrants from the Middle East and Africa). In recent years, Hungary has experimented with a package of policies aimed at boosting fertility in part by encouraging early marriage, and restoring more traditional marriage patterns. Early evidence suggests that this approach has raised fertility rates, though not quite to replacement levels (Stone, 2018a).

So far, family leave policies, subsidized childcare, and cash transfers to families who care for their children at home seem to have a small positive effect on birth rates (Thevenon and Gauthier, 2010). Recent evidence suggests that women in developed countries like the US and UK want more children than they are having, and that couples who are married and have a stable income are more likely to achieve their fertility goals (Stone, 2018b, 2018c). But it is not clear how policies that try to promote marriage and children specifically affect the fertility of professionals, or what effect they have on the average intelligence of a country's population. ${ }^{7}$

\subsubsection{Religious Belief}

Religious belief powerfully influences reproductive choices. A century and a half after Darwin showed us where we come from, religious belief is alive and well across the world. This is partly because people in countries with high levels of education and income, which strongly correlate with lower levels of religious belief (e.g. England, Germany, Japan), have far fewer children than people in countries with low levels of education and income, and high levels of religious belief (e.g. Sub-Saharan African countries). It is also true that within developed countries, religious people tend to have more children than non-religious people. While religious beliefs vary in ways that matter for fertility, religiosity itself seems to positively affect both the number of children men and women have, and the number they intend to have (Zhang 2008, Hayford and Morgan 2009, Peri-Rotem 2016).

To the extent that psychological traits that predict religiosity are heritable, and strongly correlate with fertility, the world may get more religious in the near future. As Jonathan Haidt says, "Societies that forgo the exoskeleton of religion should reflect carefully on what will happen to them over several generations. We don't really know, because the first atheistic societies have only emerged in Europe in the last few decades. They are the least efficient societies ever known at turning resources into

\footnotetext{
${ }_{7}^{7}$ Intelligence is highly heritable (Plomin and Deary, 2015) and positively correlated with educational attainment (Haier, 2016), so we would expect that if professionals had a higher proportion of children, this would increase the average intelligence of the population. Moreover, some evidence indicates that support for policies that encourage some people to have more children than others increases when people are presented with evidence that intelligence, criminality, and occupational status are moderately to highly heritable (Zigerell, 2019).
} 
offspring" (2012, p. 313). In fact, religiosity may be an adaptation rather than a byproduct of other adaptive traits (Atran and Henrich, 2010). ${ }^{8}$

If these considerations are correct, one way to combat the trend of low fertility among the cognitively gifted might be to promote religious belief. However, there are many problems with social norms or public policies that try to promote religious belief. One problem is the incursion on liberty of thought that it would entail. ${ }^{9}$ While it is clear that we should respect and even emulate successful religious groups like Mormons (who encourage high levels of education and fertility), it is not obvious that religiosity in general is worth promoting. Some religions might promote norms that benefit their leaders but not their followers, as cults often do. Others might promote norms that are good for their group but bad for the broader population. For example, some religious institutions might select for excessively servile traits, like obedience to authority. Other religious institutions might select for pro-social traits like a willingness to defer to impersonal norms that serve the common good, and to punish norm violators.

It is hard to replace religion as a source of meaning in people's lives. But it is equally hard to see how a secular analogue could replace religion and spur fertility by providing the sense of purpose that for many people dissipates when they lose their religious belief. $^{10}$

\subsubsection{Community Size}

We have good reasons to believe that intelligence has network effects, and we know from behavioral genetics that assortative mating for intelligence is strong (Plomin and Deary, 2015). In other words, people tend to seek long term mates who are similar in intelligence to themselves. If people were free to form new political communities (and set the rules for new entrants), perhaps they would cluster even more along the lines of intelligence, along with other traits that have positive network effects. Less successful political communities might then copy the reproductive norms of more successful communities (though there is no guarantee this would be good, since currently the most successful communities also have the lowest birth rates). In this sense, small, stable political communities might be able to reintroduce group selection in a way that mimics the conditions that facilitated the spread of favorable psychological traits in the past. ${ }^{11}$

\footnotetext{
${ }^{8}$ This is partly because religions provide ways of clearly demarcating one's tribe, create rituals that function as costly signals and exclusionary mechanisms, and promote beliefs that tend to facilitate cooperation with the tribe.

${ }^{9}$ In a free society, religious leaders have to both mold and reflect the beliefs of their flock in order to maintain their members.

${ }^{10}$ This problem was recognized by Darwin, Nietzsche, and Dostoevsky. A character in Dostoevsky's book The Brothers Karamazov observes that "The secret of man's being is not only to live but to have something to live for. Without a firm conception of the object of life, man would not consent to go on living, and would rather destroy himself than remain on earth, though he had bread in abundance... Nothing is more seductive for man that his freedom of conscience, but at the same time nothing is a greater torture" (1879, ch 5, bk 5). ${ }^{11}$ Many traits that we value originated in part from inter-group competition (Turchin, 2015), but also through intra-group mate selection and differential success (Miller, 2007). In preindustrial England, for example, a large percentage of men who didn't possess the skills required for economic success - including industriousness - left no surviving offspring (Clark, 2007).
} 
The original idea behind American federalism is that a national government should enforce basic Constitutional rights, but smaller states and communities within a nation should control local affairs. If control over local affairs included the right to set stringent terms on who is allowed to migrate to the community, citizens of the community would presumably be more accountable to one another. ${ }^{12}$

Federalism already exists to some extent. And the concentration of talent in particular communities is leading to more assortative meeting and mating (Murray, 1996, 2012). But this is not necessarily leading to the spread of favorable reproductive norms from one community to another. However, gene-culture co-evolution occurs at a slow enough pace that it is hard to know which norms will eventually spread and which will die. Biological and cultural evolution are deeply path-dependent processes, and both are difficult to predict with any precision. Since current American cities (and cities in most countries) don't have much ability to set strong exclusionary terms on citizens, and since social welfare benefits are accessible to all, the costs of careless reproductive choices are largely externalized.

Although smaller political communities could concentrate talent in one geographic area, they might not be as economically productive as large nation states. But this isn't necessarily true: countries like Singapore and Iceland do quite well with small populations. As long as citizens in one polity trade with others, the free movement of products and ideas can occur without the continuous movement of people across borders, and without the need for massive populations within a particular country. If small, clearly defined political communities can create more responsive governments and enjoy higher levels of social innovation, especially when they worry that their citizens may leave for another political community, it is plausible that their success would translate to higher economic productivity. Productivity may be a mechanism through which the norms of one community are copied by other communities, though again there are no guarantees, especially given current demographic trends.

It may be worth encouraging autonomy among smaller political communities if for no other reason than John Stuart Mill's idea that we should encourage experiments in living (1859). As the evolutionary biologist Joseph Henrich argues, until we understand psychology and institutions better, "we should take a page from cultural evolution's playbook and design 'variation and selection systems' that will allow alternative institutions or organizational forms to compete" (2015, p. 331). Competition would increase, on this view, if communities had more freedom to experiment, and if people within communities felt the consequences of their choices more directly (Ellickson, 2001). This could create the emergence of favorable reproductive norms.

\subsubsection{Information}

If parents knew more about heredity, and about the individual advantages to their children - as well as the network effects to society - of traits like intelligence, this

\footnotetext{
${ }^{12}$ In the final chapter of Anarchy, State, and Utopia Robert Nozick (1974) defends the idea that within a minimal state (the main point of which is to establish private property rights and enforce contracts), we should honor the autonomy of different experimental political communities. Part of the idea is that no political community fits everyone's ideal type, and in order to allow people to avoid paying the costs of programs they deeply disagree with, we should give communities a greater right to determine who can join their group. This would involve a strong right to exclude non-members, while give existing members who do not break their rules freedom of exit.
} 
information would almost certainly impact their reproductive choices, which would in turn influence social norms. Informal evidence for this comes from how women select sperm donors, which reflects an intuitive but imperfect understanding of heredity. According to a recent study, women tend to select male sperm donors for intelligence and income (earned income is presumably an indicator of social success), among other factors (Whyte and Torgler, 2016). This is no surprise, given that intelligence - along with its corollaries, like creative accomplishment and a sense of humor - is ranked as a desirable trait in long term mates by both men and women (Miller, 2013). ${ }^{13}$

A lot of basic science research is not patentable, and therefore not profitable for firms to undertake (Dalrymple, 2003). This is why government investment in genetics research can boost the rate of theoretical innovation, and increase the amount of useful information that biotech firms can translate into useful products that they can temporarily patent.

Government policy, then, can influence the rate of scientific progress by adjusting IP rights and funding basic science research that yields discoveries in genetics, computation, and biochemistry. As we learn more about genetics, and more people use that knowledge to cognitively enhance their children, their behavior may influence the reproductive choices of others for two reasons. First, when high status people cognitively enhance their children, others are likely to follow suit. Second, when more parents enhance their kids, the (opportunity) cost of declining to enhance will grow. While genetic enhancement might become a positional good with decreasing returns and increasing costs, below some threshold cognitive enhancement is likely to lead to gains in economic productivity and social welfare, provided we can preserve cognitive diversity (Anomaly et al., 2019).

\section{Conclusion}

Social norms and political institutions have sculpted populations through gene-culture coevolution. Just as our genes predispose us to create certain kinds of cultures, culture can influence which genes are likely to find their way into future bodies. According to Joseph Henrich, "to the degree that we are more cooperative than other mammalian species (and we are), it's because culturally evolved norms constructed social environments that, over eons, penalized and gradually weeded out aggressive, antisocial types (norm violators) while rewarding the more sociable and docile among us" (2015, p. 154). We have offered some tentative suggestions for how political institutions and public policies might give rise to norms that nudge people (without forcing them) to reproduce in ways that increase the prevalence of traits that bolster human welfare. If selecting for cognitive abilities becomes a social norm, social cooperation may very well increase as a byproduct. However, our suggestions are tentative because our information is limited, our political institutions are imperfect, and the relevant sciences are still developing.

\footnotetext{
${ }^{13}$ Interestingly, recent studies suggest that being in the 90th percentile of intelligence is most attractive, but as we go above this, attractiveness tends to flatten and even decline a bit (Gignac and Starbuck, 2019; Gignac et al., 2018). It may be, however that when we move from the mating market to the fertility clinic different traits will be selected. What we want in a partner and in a child may be related, but the fertility clinic isn't hampered by an individual's ability to attract and retain a partner.
} 
Open Access This article is licensed under a Creative Commons Attribution 4.0 International License, which permits use, sharing, adaptation, distribution and reproduction in any medium or format, as long as you give appropriate credit to the original author(s) and the source, provide a link to the Creative Commons licence, and indicate if changes were made. The images or other third party material in this article are included in the article's Creative Commons licence, unless indicated otherwise in a credit line to the material. If material is not included in the article's Creative Commons licence and your intended use is not permitted by statutory regulation or exceeds the permitted use, you will need to obtain permission directly from the copyright holder. To view a copy of this licence, visit http://creativecommons.org/licenses/by/4.0/.

\section{References}

Almlund, M., et al. (2011). Personality psychology and economics. Handbook of the Economics of Education, $4,1-181$.

Anomaly, J. (2017). Trust, trade, and moral Progress. Social Philosophy and Policy, 34(2), 89-107.

Anomaly, J., Gyngell, C., \& Savulescu, J. (2019). Great minds think different: Preserving cognitive diversity in an age of gene editing. Bioethics. https://onlinelibrary.wiley.com/doi/epdf/10.1111/bioe.12585.

Anomaly, J. (2020). Creating future people: The ethics of genetic enhancement. New York and London: Routledge Publishing.

Atran, S., \& Henrich, J. (2010). The evolution of religion. Biological Theory, 5(1), 18-30.

Azam, S. (2017). A cross-country empirical test of cognitive abilities and innovation nexus. Intelligence, 53, $128-136$.

Benjamin, D., et al. (2013). Who is behavioral? Cognitive ability and anomalous preferences. Journal of the European Economic Association, 11(6). https://doi.org/10.1111/jeea.12055.

Bostrom, N., \& Sandberg, A. (2009). Cognitive enhancement: Methods, ethics, regulatory challenges. Science and Engineering Ethics, 15, 311-341.

Bowles, S., \& Gintis, H. (2011). A Cooperative Species: Human Reciprocity and itsEvolution. Princeton University press. Science and Engineering Ethics, 15, 311-341.

Buchanan, Allen. 2011. Better than human: The promise and perils of biomedical enhancement. Oxford University Press.

Caplan, B., \& Miller, S. (2010). Intelligence makes people think like economists: Evidence from the general social survey. Intelligence, 38, 636-647.

Clark, Gregory. 2007. A farewell to alms: A brief economic history of the world. Princeton University Press.

Christelis, D., Jappelli, T., \& Padula, M. (2010). Cognitive abilities and portfolio choice. European Economic Review, 54(1), 18-38.

Dalrymple, Dana. 2003. Scientific knowledge as a global public good. In The Role of Scientific and Technical Data and Information in the Public Domain. National Academies Press.

Darwin, Charles. 1871. The descent of man.

Darwin, Charles. 1872. The expression of emotions in man and animals.

De Dreu, C., et al. (2010). The neuropeptide oxytocin regulates parochial altruism in intergroup conflict among humans. Science, 328(5984), 1408-1411.

Dohmen, T., et al. (2010). Are risk aversion and impatience related to cognitive ability? The American Economic Review, 100(3), 1238-1260.

Dostoevsky, Fyodor. 1879. The Brothers Karamazov. https://www.gutenberg.org/files/28054/28054-h/28054h.html. Accessed 02/02/2019.

Douglas, T., \& Devolder, K. (2013). Procreative Altruism. Journal of Medicine and Philosophy, 38, 400-410.

Ellickson, R. (2001). The market for social norms. American Law and Economics Review, 3(1), 1-49.

Frank, R. (1988). Passions within reason: The strategic role of emotions. New York: WW Norton \& Company.

Frank, Robert. 2001. Cooperation through emotional commitment. In Evolution and the Capacity for Commitment, ed by Rudoph Nesse. New York: Russel Sage Foundation.

Gignac, Gilles; Joey Darbyshire; and Michelle Ooi. 2018. Some people are attracted sexually to intelligence. Intelligence 66, 98-111.

Gignac, G., \& Starbuck, C. (2019). Exceptional intelligence and easygoingness may hurt your prospects: Threshold effects for rated mate characteristics. The British Journal of Psychology, 110, 151-172.

Gyngell, C., \& Douglas, T. (2015). Stocking the genetic supermarket: Reproductive genetic technologies and collective action problems. Bioethics, 29(4), 241-250. 
Gordon, R. (1997). Everyday life as an intelligence test. Intelligence, 24(1), 203-320.

Grinblatt, M., Keloharju, M., \& Linnainmaa, J. (2011). IQ and stock market participation. The Journal of Finance, 66(6), 2121-2164.

Haidt, J. (2012). The righteous mind. New York: Vintage Publishing.

Haier, Richard. 2016. The neuroscience of intelligence. Cambridge University Press.

Hayek, Friedrich. 1960. The constitution of liberty. University of Chicago Press.

Hayford, S., \& Morgan, P. (2009). Religiosity and fertility in the United States. Social Forces, 86(3), 11631188.

Henrich, Joseph. 2015. The secret of our success. Princeton University Press.

Jones, G. (2016). Hive mind: How your Nation's IQ matters so much more than your own. Palo Alto: Stanford University Press.

Jones, G., \& Potrafke, N. (2014). Human capital and national institutional quality: Are TIMSS, PISA, and national average IQ robust predictors? Intelligence, 46, 148-155.

Kanazawa, S. (2014). Intelligence and childlessness. Social Science Research, 48, 157-170.

Kanyama, I. (2014). Quality of institutions: Does intelligence matter? Intelligence, 42, 44-52.

Kremer, M. (1993). The O-ring theory of economic development. The Quarterly Journal of Economics, 108(3), 551-575.

McAdams, R. (1997). The origin, development, and regulation of norms. Michigan Law Review, 96, 338-433.

Mill, John Stuart. 1859. On Liberty. https://www.gutenberg.org/files/34901/34901-h/34901-h.htm. Accessed $02 / 02 / 2019$.

Miller, G. (2007). Sexual selection for moral virtues. The Quarterly Review of Biology, 82(2), 97-125.

Miller, G. (2013). Mutual mate choice models as the red pill in evolutionary psychology. Psychological Inquiry, 24, 207-210.

Murray, C. (1996). The bell curve: Intelligence and class structure in American life. New York: Free Press Books.

Murray, C. (2012). Coming Apart. New York: Crown Publishing.

Ostrom, E. (2000). Collective action and the evolution of social norms. The Journal of Economic Perspectives, 14(3), 137-158.

Nozick, R. (1974). Anarchy, state, and utopia. New York: Basic Books.

Peri-Rotem, N. (2016). Religion and fertility in Western Europe. European Journal of Population, 32(2), 231265.

Persson, I., \& Savulescu, J. (2017). Hard-wiring and moral enhancement. Bioethics, 31(4), 286-295.

Plomin, R. (2018). Blueprint: How DNA makes us who we are. Cambridge: MIT Press.

Plomin, R., \& Deary, I. (2015). Genetics and intelligence differences: Five special findings. Molecular Psychiatry, 21(1), 98-108.

Potrafke, N. (2012). Intelligence and corruption. Economic Letters, 114(1), 109-112.

Powell, R., \& Buchanan, A. (2011). Breaking Evolution's chains: The Prospect of deliberate genetic modification in humans. Journal of Medicine and Philosophy, 36, 6-27.

Powell, Russell and Allen Buchanan. 2016. The evolution of moral enhancement. In The Ethics of Human Enhancement: Understanding the Debate, edited by Steve Clarke et al. Oxford University Press.

Proto, E., Rustichini, A., \& Sofianos, A. (2019). Intelligence, personality, and gains from cooperation in repeated interactions. Journal of Political Economy, 127(3). https://doi.org/10.1086/701355.

Richerson, Peter and Robert Boyd. 2005. Not by genes alone: How culture transformed human evolution. University of Chicago Press.

Savulescu, J., \& Kahane, G. (2009). The moral obligation to produce children with the best chance of the best life. Bioethics, 23(5), 274-290.

Schulz, J., et al. (2019). The church, intensive kinship, and global psychological variation. Science, 377(707), $1-12$.

Seabright, P. (2004). The company of strangers: A natural history of economic life. Princeton: Princeton University Press.

Smith, Adam. 1776. An Inquiry into the Nature and Causes of the Wealth of Nations. https://oll.libertyfund. org/titles/smith-an-inquiry-into-the-nature-and-causes-of-the-wealth-of-nations-cannan-ed-vol-1.

Sparrow, R. (2014). In vitro eugenics. Journal of Medical Ethics, 40, 725-731.

Shulman, C., \& Bostrom, N. (2014). Embryo selection for cognitive enhancement: Curiosity or game changer? Global Policy, 5(1), 85-92.

Stone, Lyman. 2018a. Is Hungary experiencing a policy-induced baby boom? Institute for Family Studies. URL: https://ifstudies.org/blog/is-hungary-experiencing-a-policy-induced-baby-boom. Accessed February 1, 2020. 
Stone, Lyman. 2018b. How many kids do women want? Institute for Family Studies. URL: https:/ifstudies. org/blog/how-many-kids-do-women-want. Accessed February 1, 2020.

Stone, Lyman. 2018c. No ring, No Baby: How Marriage Trends Impact Fertility. URL: https://ifstudies. org/blog/no-ring-no-baby. Accessed February 1, 2020.

Thevenon, O., \& Gauthier, A. (2010). Family policies in developed countries: A 'fertility booster' with side effects. Community, Work, and Family, 14(2), 197-216.

Turchin, Peter. 2015. Ultrasociety: How 10,000 years of war made humans the greatest cooperators on earth. Beresta Books.

Whyte, S., \& Torgler, B. (2016). Determinants of online sperm donor success: How women choose. Applied Economic Letters, 23(8), 592-596.

Wilson, D., \& Wilson, E. O. (2007). Rethinking the Theoretical Foundation of sociobiology. The Quarterly Review of Biology, 82(4), 327-348.

Zhang, L. (2008). Religious affiliation, religiosity, and male and female fertility. Demographic Research, $18(8), 233-262$.

Zigerell. (2019). Understanding public support for eugenic policies. The Social Science Journal. https://doi. org/10.1016/j.soscij.2019.01.003.

Publisher's Note Springer Nature remains neutral with regard to jurisdictional claims in published maps and institutional affiliations. 